КЛУБАНЬ М.В.

\title{
ІНФОРМАЦІЙНА КУЛЬТУРА В РАЗІ ВПРОВАДЖЕННЯ ЕЛЕКТРОННОЇ ОСВІТИ
}

В умовах формування інформаційного суспільства інформаційна культура стає його невід'ємною складовою частиною, необхідною умовою для успішної діяльності у будь-якій сфері. Інформаційна культура - це складне та багатозначне поняття, яке пронизує усі сторони розвитку людини. Проблема формування інформаційної культури є однією з найважливіших проблем сьогодення.

У процесі становлення інформаційного суспільства в Україні електронна освіта відіграє важливу роль, оскільки спрямована на реалізацію ідеї освіти протягом всього життя. Такий підхід націлений подолати суперечності сучасної освітньої системи, а саме між стрімким темпом накопичення знань у світі та обмеженими можливостями їх засвоєння здобувачем освіти в період навчання. Така суперечність змушує заклади освіти формувати вміння вчитися, знаходити необхідну інформацію, здобувати інформацію, отримувати з неї необхідні знання. Особливого значення при цьому набуває інформаційна культура здобувача освіти, викладача, а в майбутньому і фахівця, що є однією з базових особистісних характеристик, яка визначає сучасне інформаційне мислення, а в подальшому і професійну мобільність.

Інформаційна культура сприяє значній ефективності не тільки професійній діяльності сучасного фахівця, а й його самоосвіті, що важливо в умовах швидкого старіння знань та їх частого оновлення. Такий підхід забезпечує підготовку фахівців нового покоління як гармонійно та всебічно розвиненої особистості.

Стаття присвячена дослідженню поняття «інформаційна культура». Особливу вагу приділено значенню інформаційної культури у процесі впровадження електронної освіти. Акцентується на відсутності належного законодавчого регулювання розвитку інформаційної культури та необхідності врегулювання цього питання на законодавчому рівні та введення такої дисципліни, як «інформаційна культура». Наголошено на важливій ролі підготовки науково-педагогічних кадрів, здатних на високому професійному рівні викладати дисципліни, пов'язані з освоєнням інформаційної культури. Визначено умови успішного вирішення завдання формування інформаційної культури майбутнього фахівця.

Ключові слова: електронне навчання, електронна освіта, інформачійна культура, інформаційне суспільство, інформатизачія.

In the context of the formation of the information society, information culture becomes an integral part, a prerequisite for successful activity in any field. Information culture is a complex and meaningful concept that permeates all aspects of human development. The problem of forming an information culture is one of the most important problems of today.

In the development of the information society in Ukraine, e-education plays an important role, as it aims to implement the idea of lifelong learning. This approach is aimed at overcoming the contradictions of the modern educational system, namely between the rapid pace of knowledge accumulation in the world and the limited possibilities of their acquisition by the acquirer of education in the period of study. Such contradiction forces educational institutions to form the ability to learn, to find the necessary information, to obtain information, to obtain from it the necessary knowledge. Of particular importance is the information culture of the educator, teacher, and in the future, the specialist, which is one of the basic personal characteristics that determines modern information thinking, and subsequently, professional mobility.

(C) КЛУБАНЬ М.В. - кандидат юридичних наук, викладач кафедри правоохоронної діяльності та поліції стики (Харківський національний університет внутрішніх справ) 
Information culture contributes not only to the professional activity of a modern specialist but also to his / her self-education, which is very important in the conditions of rapid aging of knowledge and their frequent updating. This approach provides training for the next generation of professionals as a harmoniously and comprehensively developed personality.

The article is devoted to the study of the concept of "information culture". Particular importance is attached to the importance of information culture in the implementation of e-learning. Emphasis is placed on the lack of proper legislative regulation of the development of information culture and the need to regulate this issue at the legislative level and the introduction of such discipline as "information culture". Emphasis is placed on the important role of training scientific and pedagogical staff capable of teaching, at a high professional level, disciplines related to the development of information culture. The conditions for successful solution of the task of forming the information culture of the future specialist are determined.

Key words: e-education, e-learning, information culture, information society, informatization.

Вступ. Враховуючи стрімкий розвиток інформаційних технологій, інформаційним суспільством можна вважати суспільство постійного навчання, оскільки всі сучасні люди вимушені навчатися все своє життя. Інтернет не тільки прискорив інформаційні потоки, а й створив нові варіанти інформаційного існування людини. Людина проводить у цьому інформаційному середовищі набагато більше часу, ніж це було в минулому. У сучасних умовах розвитку інформаційних технологій зростає значення інформаційної культури в умовах постійного навчання.

Постановка завдання. Метою статті є дослідити поняття «інформаційна культура», визначити роль інформаційної культури викладача та здобувача освіти у процесі впровадження електронної освіти.

Результати дослідження. Рівень інформаційної культури здобувачів освіти та викладачів, а також свідомих громадян $\epsilon$ певним показником розвитку інформаційного суспільства в Україні. В умовах інформатизації навчального процесу на всіх освітніх рівнях не варто залишати поза увагою дослідження інформаційної культури.

Цією проблемою безпосередньо займалися вітчизняні науковці В.Б. Аверьянов, І.В. Арістова, К.І. Бєляков, В.М. Брижко, В.М. Глушков, І.О. Здеба, Р.А. Калюжний, А. В. Колодюк, Б.А. Кормич, В.В. Костицький, Д.В. Ланде, П.В. Мельник, Н.Р. Нижник, Н.Б. Новицька, С.Г. Онупрієнко, В.А. Саницький, В.П. Пєтков, В.М. Попович, О.Г. Фролова, В.М. Фурашев, В.С. Цимбалюк, М.Я. Швець, Ю.С. Шемшученко, В.К. Шкарупа.

Людина сучасного суспільства вже має сформовану звичку отримувати знання з використанням можливостей сучасних інформаційних технологій, проте відсутнє формування інформаційної культури. Вміння правильно працювати на комп'ютері, інтернеті, корпоративних мережах, тобто наявність знань і вмінь в області використання інформаційних технологій, ознайомленість 3 юридичними і етичними нормами в цій сфері і $є$ інформаційною культурою. Тому при впровадженні електронної освіти, поряд із культурою професії, необхідно передавати інформаційну культуру та здатність знаходити потрібну, правдиву та фахову інформацію, прищеплювати навички критичного мислення та осмислення отриманої інформації.

Сучасна людина існує в світі інформації. Інформація виступає як єдність об'єктивного знання і універсальних цінностей, що відповідають інтересам буття людини [1, с. 59]. У контексті ставлення людини до інформації, іiі оцінки, відбору для практичного використання, організації сумісної інформаційної діяльності виникає проблема інформаційної культури [1, с. 5]. Інформаційна культура - це нове поняття, яке «відображає глибинні тенденції, які вже довгий час осмислюють із різних боків» [1, с. 9]. Ці «глибинні тенденції» зумовлені історично досягнутим рівнем розвитку сучасного суспільства.

На думку В.С. Цимбалюк, інформаційна культура - це якісна оцінка за певними критеріями (умовами) рівня функціонування структурних одиниць суспільства (окремих індивідів, підрозділів та конкретної соціальної системи загалом як сфери суспільних відносин) щодо скеровування технологічного забезпечення отримання, передачі, зберігання і використання інформації щодо досягнення узгоджених і визначених нормативно в суспільстві цілей, завдань, інтересів, потреб [2, с. 34]. 
Н.Б. Новицька виділяє три підходи щодо самого поняття «інформаційна культура» [3]. 3 погляду інформаційного підходу інформаційна культура - це сукупність знань, умінь і навичок пошуку, відбору, аналізу інформації, тобто все те, що належить до інформаційної діяльності, спрямованої на задоволення інформаційних потреб. При такому підході визначення інформаційної культури, на її думку, базуються тільки на інформації, що значно звужує саме поняття «інформаційна культура», оскільки відображає лише таку ії складову частину, як комп'ютерна чи інформаційна грамотність. У культурологічному аспекті інформаційна культура розглядається як невід'ємна складова частина загальної культури особистості, як галузь культури, пов'язана 3 функціонуванням інформації в суспільстві та формуванням інформаційних якостей особистості; вона включається у загальнолюдську культуру і $є$ її інформаційною складовою; гармонізує внутрішній світ особистості під час освоєння соціально необхідної інформації. 3 точки зору інформаційного підходу до інформаційної культури остання визначається як методика, методологія та світогляд суспільства епохи інформатизації в зв'язку з тим, що знання про інформаційні закони, засоби взаємодії з інформацією стають основою, методологією епохи інформаційного суспільства [3, с. 33-35.].

К.І. Бєляков у своїх ранніх роботах визначав інформаційну культуру як стан інформаційного спадку, який виражений в інформаційно-технологічних навичках (інформаційна грамотність), інформаційній свідомості, мисленні, всіх різновидах інформаційної діяльності, рівні правового регулювання сфери інформаційних відносин [4, с. 143]. Водночас, як справедливо зазначає А.А. Колодюк, «інформаційна свідомість визнається первинним (основоположним елементом) побудови концепції інформаційного суспільства на усіх можливих рівнях» [5, с. 118] і «видається як особлива форма суспільної свідомості, що є передумовою інформаційної діяльності та підставою виникнення й динаміки інформаційного суспільства і виявляється в ідеях, знаннях, доктринах, цінностях, емоціях, ставленні тощо стосовно інформації та інших інформаційних явищ» [6, с. 111].

У монографії «Інформаційна культура. Правовий вимір» колектив авторів таких, як К.І. Бєляков, С.Г. Онопрієнко, І.М. Шопіна [7, с. 31], розглядає поняття «інформаційна культура» як інтегральну цілісність, що включає світоглядні ціннісні, когнітивні, комунікативні та інструментальні компоненти життєдіяльності людини, соціальних груп та держави, які в сукупності спрямовані на формування інформаційного суспільства, виступають орієнтиром розвитку інформаційного законодавства і знаходять свій прояв в інформаційній діяльності та забезпеченні інформаційної безпеки.

Л.С. Винарик і А.І. Щедрін вносять у формулювання Е.П. Семенюка «невелике уточнення», яке, на їх погляд, має його конкретизувати: «Інформаційна культура - це рівень практичного досягнення розвинутості інформаційної взаємодії і всіх інформаційних відносин у суспільстві, міра досконалості в оперуванні будь-якою необхідною інформацією» [8, с. 37].

У працях Е.П. Семенюка [9, с. 10] інформаційна культура визначається як інформаційний компонент людської культури загалом, який об'єктивно характеризує ступінь розвитку інформаційної взаємодії і всіх інформаційних взаємовідносин у суспільстві як інтегральне позначення рівня досконалості суспільства (людини) саме в інформаційній сфері діяльності [10].

Зазначається також, що під інформаційною культурою розуміється сукупність ії складових частин: нових інформаційних технологій, технологічної, правової, соціологічної і ергономічної, які інформують людину і впливають на протікання соціальних процесів у суспільстві, колективі і виховання свідомого ставлення людини до праці, прав і обов'язків [8, с. 37].

Основними факторами розвитку інформаційної культури сучасного суспільства $є$ : система освіти, яка визначає загальний рівень інтелектуального розвитку людей, їхніх матеріальних та духовних потреб; інформаційно-комунікаційна інфраструктура суспільства, яка визначає можливості людей своєчасно одержувати, передавати і використовувати необхідні їм відомості, а також оперативно здійснювати ті чи інші інформаційні комунікації; демократизація суспільства, яка визначає правові гарантії доступу людей до необхідних їм відомостей; розвиток економіки країни, від якого залежать матеріальні можливості одержання людьми необхідної освіти, а також придбання і використання сучасних засобів інформаційної техніки [11, с. 167].

На особливу увагу заслуговує проблема формування інформаційної культури педагогічного працівника, оскільки він $є$ ключовою фігурою проведення в життя ідеології сучасних інформаційних та комунікаційних технологій, інформатизації освітнього процесу, формування інформаційної культури учнів, підготовки підростаючого покоління до повноцінної плідної життєдіяльності в інформаційному суспільстві, підвищення якості, доступності та ефективності освіти $[12$, с. 11$]$. 
Отже, формування інформаційної культури - це процес, внаслідок якого формуються інформаційні компетенції фахівців, тобто знання вміння та навички, що дають змогу орієнтуватися в інформаційному просторі, брати участь у його формуванні та сприяти розвитку інформаційних комунікацій. До інформаційних компетенцій фахівців як складників інформаційної культури належать: потреба в інформації, вміння знаходити інформацію, здатність критично оцінювати знайдену інформацію з точки зору іiї актуальності, надійності та всебічності, вміння ефективно використовувати інформацію в навчанні, праці, в будь-якій діяльності, вміння створювати якісний власний конкурентоспроможний, необхідний іншим інформаційний продукт.

На рівні законодавства як публічно-правову категорію термін «інформаційна культура» було введено в Концепції Національної програми інформатизації, де під інформаційною культурою розуміли комп'ютерну грамотність людини [13]. Проте подальший розвиток та закріплення в чинному законодавстві стратегії навчання інформаційної культури не тільки викладачів, а й інших фахівців відсутній.

Також в Україні відсутній єдиний державний орган, який би займався питаннями формування, підтримки та розвитку інформаційної культури, впровадження ії як дисципліни в закладах освіти. Так, на Міністерство розвитку економіки, торгівлі та сільського господарства покладено обов'язок брати участь у формуванні та реалізації державної політики у сфері інформатизації, розвитку електронного урядування, побудові сучасного інформаційного суспільства в державі, забезпечує в межах повноважень, передбачених законом, впровадження сучасних інформаційно-комунікаційних технологій, створення системи національних інформаційних ресурсів [14].

Указом Президента України було введено в дію рішення Ради національної безпеки і оборони України «Про заходи щодо вдосконалення державної інформаційної політики та забезпечення інформаційної безпеки України» [15]. Відповідно до п. 9 цього Указу Міністерству освіти і науки України було доручено підготувати у тримісячний строк типові навчальні програми для середніх і вищих навчальних закладів із навчальної дисципліни «Інформаційна культура», проте це рішення залишилось виключно декларативним.

Висновки. Інформаційне суспільство - це своєрідний етап життєдіяльності цивілізації, який базується на інтелекті. А таке поняття, як «інформаційна культура», з'являється із розвитком інформаційного суспільства, головною особливістю якого $є$ переважання інформаційної діяльності в усіх сферах суспільного життя, мистецтві, бізнесі, освіті і здійснення інформаційної взаємодії на основі інформаційних технологій.

Глобальне інформаційне суспільство можна побудувати лише за умови формування нової інформаційної культури особистості, корпоративної інформаційної культури, інформаційної культури суспільства і держави, інформаційної культури цивілізацій.

У чинному законодавстві України не приділено уваги закріпленню та регулюванню основних суспільних цінностей нового інформаційного суспільства, зокрема інформаційній культурі.

Варто не лишати поза увагою, що формування інформаційної культури відбувається саме в процесі здобуття освіти. I саме у процесі впровадження електронної освіти варто приділити належної уваги формуванню інформаційної культури у здобувачів освіти. Тому вважаємо, що має бути розроблений та закріплений на законодавчому рівні нормативно-правовий акт, який би регулював впровадження такої навчальної дисципліни, як «інформаційна культура».

\section{Список використаних джерел:}

1. Виноградов В.А., Скворцов Л.В. Создание информационной культуры для Европы : доклад на VI конференции ЕКССИД. Теория и практика общественно-научной інформатики. 23-25 марта 1991 г. Кентербери, Великобритания. 1991. № 2. С. 5-29.

2. Цимбалюк В. Проблеми формування інституту інформаційної культури в теорії інформаційного права України. Правова інформатика. 2003. № 1. С. 31-36.

3. Новицька Н.Б. Організаційно-правові аспекти інформаційної культури в управлінській діяльності : дис. ... канд. юрид. наук : 12.00.07. Ірпінь, 2007. 210 с.

4. Бєляков К.І. Інформатизація в Україні : Проблеми організаційного, правового та наукового забезпечення : монографія. Київ : КВІЦ, 2008. 576 с.

5. Колодюк А.В. Інформаційне суспільство : сучасний стан та перспективи розвитку в Україні : дис. ... канд. політ. наук : 23.00.03. Київ, 2004. 234 с.

6. Селезньова О.М. Аналіз явища інформаційної свідомості з позиції інформаційного права. Наука і правоохорона. 2015. № 2. С. 110-115.

7. Інформаційна культура в Україні : правовий вимір : монографія / К.І. Бєляков, С.Г. Онупрієнко, І.М. Шопіна ; за заг. ред. К.І. Бєлякова. Київ : КВІЦ, 2018. 169 с. 
8. Винарик Л.С., Щедрин А.Н. Информационная культура : эволюция, проблемы. Донецк : ИЭП НАН Украины, 1999. 144 с. № 1. C. 1-7.

9. Семенюк Э.П. Информатизация общества, культура, личность. НТИ. Серия 1. 1993.

10. Семенюк Е.П. Перспективи розвитку інформаційної культури в Україні. Інформатизачія та нові технології. 1993. № 23. С. 11-13.

11. Колин К.К. Фундаментальные основы информатики : социальная информатика : учеб. пособие для вузов. Москва : Академический проспект, 2000. 350 с.

12. Кремень В.Г. Українська освіта в добу глобалізації. Директор школи, лічею, гімназії : науково-практичний журнал для керівників закладів освіти. 2002. № 6. С. 4-12.

13. Про Концепцію Національної програми інформатизації: Закон України від 04.02.1998 p. № 75/98-BP. URL: http://zakon.rada.gov.ua/laws/show/75/98-\%D0\%B2\%D1\%80 (дата звернення 01.03.2020).

14. Положення про Міністерство розвитку економіки, торгівлі та сільського господарства України : затверджено постановою Кабінету Міністрів України від 20 серпня 2014 р. № 459. URL: https://zakon.rada.gov.ua/laws/show/459-2014-\%D0\%BF\#top (дата звернення 01.03.2020).

15. Про заходи щодо вдосконалення державної інформаційної політики та забезпечення інформаційної безпеки України : Указ Президента Про рішення Ради національної безпеки і оборони України від 31 жовтня 2001 p. URL: http://zakon.rada.gov.ua/laws/show/1193/2001. (дата звернення 01.03.2020). 